This is a self-archived version of an original article. This version may differ from the original in pagination and typographic details.

Author(s): Butler, Patrick W. V.; Ward, James S.

Title: The Synthesis of Quinoline-based Tin Complexes with Pendant Schiff Bases

Year: 2019

Version: Accepted version (Final draft)

Copyright: @ 2019 WILEY-VCH Verlag GmbH \& Co. KGaA, Weinheim

Rights: In Copyright

Rights url: http://rightsstatements.org/page//nC/1.0/?language=en

Please cite the original version:

Butler, P. W. V., \& Ward, J. S. (2019). The Synthesis of Quinoline-based Tin Complexes with Pendant Schiff Bases. Zeitschrift für Anorganische und Allgemeine Chemie, 645(9), 694-699. https://doi.org/10.1002/zaac.201900063 


\title{
The Synthesis of Quinoline-based Tin Complexes with Pendant Schiff Bases
}

\author{
Patrick W. V. Butler, ${ }^{[a]}$ and Jas S. Ward ${ }^{\star[a][b]}$
}

\begin{abstract}
Whilst pursuing the synthetic utility of quinoline-based tin complexes, $\mathrm{Me}_{2} \mathrm{Sn}$ (Quin- $\left.\mathrm{NO}_{2}\right)_{2}$ (1; Quin- $\mathrm{NO}_{2}=5$-nitroquinolino-8oate) and $\mathrm{Ph}_{2} \mathrm{Sn}\left(\text { Quin- } \mathrm{NO}_{2}\right)_{2}$ (2) were synthesised bearing coordinatively inert nitro groups. Conventional reduction methodologies successfully converted 1 to $\mathrm{Me}_{2} \mathrm{Sn}\left(\mathrm{Quin}-\mathrm{NH}_{2}\right)_{2}$ (3; Quin- $\mathrm{NH}_{2}=5$-aminoquinolino-8-oate) and 2 to $\mathrm{Ph}_{2} \mathrm{Sn}\left(\text { Quin- }-\mathrm{NH}_{2}\right)_{2}$ (4). The synthetically useful amine groups proved difficult to exploit in the presence of the tin centre, however, a complete Schiff base functionalised $\mathrm{Sn}$ complex of the dimethyltin pro-ligand $\mathrm{Me}_{2} \mathrm{Sn}$ (Quinpy $)_{2}$ (6) was successfully synthesised from 5-((pyridin-2ylmethylene)amino)quinolin-8-ol (HQuin-py; 5) in good yield via an alternative strategy exploiting the oxophilic tendencies of tin. All species were fully characterised by NMR (including ${ }^{119} \mathrm{Sn}$ NMR spectroscopy), HR-ESI MS and single-crystal X-ray diffraction, and preliminary studies of their supramolecular potential will also be discussed.
\end{abstract}

\section{Introduction}

The flexibility of tin to adopt a range of coordination states and bonding modes has led to the development of a diverse array of structures from discrete mononuclear complexes ${ }^{[1,2]}$ to clusters, ${ }^{[3]}$ and polymers. ${ }^{[4,5]}$ Organotin complexes in particular have been shown to possess significant chemical utility in terms of catalysis, finding prominent application over the last two decades in $\mathrm{CO}_{2}$ fixation to form carbonates ${ }^{\left[{ }^{[}\right]}$and the esterification and transesterification important to biodiesel production. ${ }^{7,8]}$ Tin complexes of ester-functionalized quinolines, ${ }^{[9,10]}$ and other metal complexes incorporating 8-hydroxyquinoline (Quin) such as $\mathrm{Ga}(\text { Quin })_{3}{ }^{[11]}$ have been previously synthesized for a variety of uses, with particular interest in the study of their medicinal potential. ${ }^{[12]}$ Furthermore, Sn-O bonds have been shown to be useful synthetic precursors, in particular in the ring-opening polymerization (ROP) of caprolactone, which was successfully performed on templated catenanes to expand the sizes of the catenated rings. ${ }^{[13]}$

The structural flexibility of tin further suggests it would be amenable to incorporation in a variety of multi-metallic systems.

[a] Research School of Chemistry

Australian National University

Canberra, ACT

Australia

[b] Department of Chemistry, Nanoscience Center

University of Jyvaskyla

Jyvaskyla 40014

Finland

james.s.ward@jvu.fi

Supporting information for this article can be downloaded electronically.
The development of homometallic and heterometallic systems has yielded catalysts with both improved catalytic activity and specificity, and in select cases, capable of catalyzing multi-step reactions. ${ }^{[14-16]}$ Consequently, the investigation of multi-metallic structures is a continuing and expanding focus of catalysis research presently.

A common motif in multi-metallic systems is the conjugated pyridyl-imine ligand which provides a strong and favorable bidentate binding site for a large variety of metal centers. ${ }^{[17]}$ Beside strong chelating characteristics and tunable electronic properties, the functionality is further benefited by being readily accessible from amine functionalized precursors by either a conventional acid-catalyzed imine-condensation beforehand or via self-assembly in-situ in combination with Lewis acidic metals. ${ }^{[18,19]}$ The scarcity of examples of multi-metallic and supramolecular systems of Schiff base functionalized tin complexes was notable and warranted further investigation Herein we report the synthesis of new organotin complexes with pendant Schiff bases using a functionalized quinoline-based ligand system.

\section{Results and Discussion}

The first step toward 6-coordinate complexes involved the formation of the nitro precursor complexes 1 and 2 . These reactions proceeded smoothly in good yield $(79 \%$ and $73 \%$, respectively; Scheme 1) by the reaction of the organotin reagents, $\mathrm{R}_{2} \mathrm{SnCl}_{2}(\mathrm{R}=\mathrm{Me}, \mathrm{Ph})$ with two equivalents of $\mathrm{HQuin}-\mathrm{NO}_{2}$ in the presence of a stoichiometric amount of $\mathrm{NEt}_{3}$. This methodology proved an improvement over other previously prepared tin quinoline complexes that were recovered in lower yields. ${ }^{[20]}$

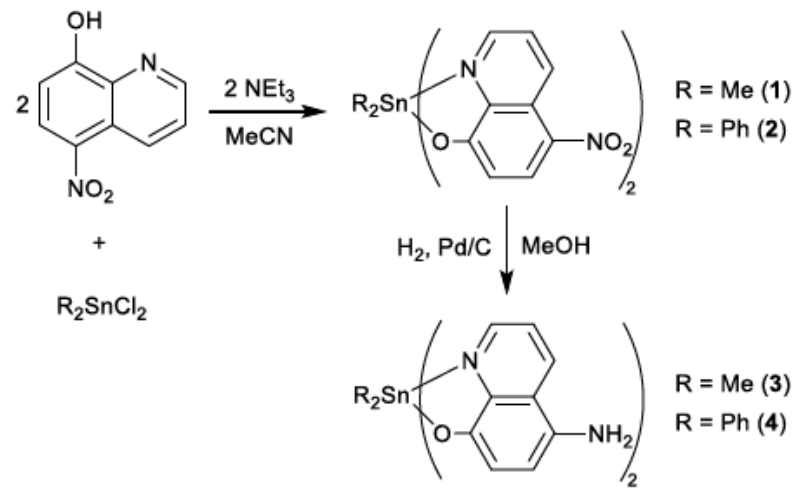

Scheme 1. The reactions of $\mathrm{R}_{2} \mathrm{SnCl}_{2}(\mathrm{R}=\mathrm{Me}, \mathrm{Ph})$ with $\mathrm{HQuin}-\mathrm{NO}_{2}$ to form $\mathrm{R}_{2} \mathrm{Sn}$ (Quin- $\left.\mathrm{NO}_{2}\right)_{2}$ (1 and 2), followed by reduction to the amine-functionalised $\mathrm{R}_{2} \mathrm{Sn}\left(\mathrm{Quin}-\mathrm{NH}_{2}\right)_{2}$ complexes (3 and 4). 
The resulting 6-coordinate complexes were sufficiently stable to allow full (structural) characterization, including by X-ray diffraction. Additionally, ${ }^{119} \mathrm{Sn}$ NMR spectroscopy identified the dimethyl (1) and diphenyl (2) complexes as sharp singlets at -214 and $-381 \mathrm{ppm}$, respectively. In the case of $1,{ }^{1} \mathrm{H}-{ }^{119} \mathrm{Sn}$ coupling was notably observed, manifesting as satellite resonances around the methyl peak in the ${ }^{1} \mathrm{H}$ NMR spectrum (see ESI Page $\mathrm{S} 6$ ). The corresponding ${ }^{13} \mathrm{C}-{ }^{119} \mathrm{Sn}$ coupling was not observed in any experiment, though this was not unexpected due to the relatively low abundances of both the ${ }^{13} \mathrm{C}(1.1 \%)$ and ${ }^{119} \mathrm{Sn}(8.6 \%)$ nuclei. Examination of the molecular structures (Figure 1 and Figure S2) shows the trans-oxygen-cis-nitrogen arrangement to be favored. The C-Sn-C angles were found to be $107.9^{\circ}$ (Me-Sn$\mathrm{Me}$ ) and $106.5(2)^{\circ} / 113.3(2)^{\circ}$ (Ph-Sn-Ph; two crystallographically

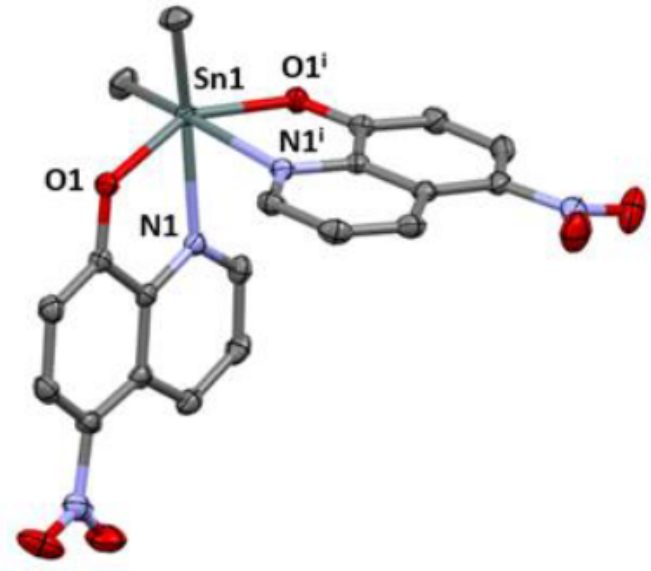

distinguishable molecules were present in the asymmetric unit cell), with the complexes adopting a heavily distorted octahedral geometry. This distorted geometry notably creates an acute angle between the planes of the two quinoline substituents in both complexes, measured to be $79.5^{\circ}$ and $79.3^{\circ} / 84.4^{\circ}$ for the dimethyl (1) and diphenyl (2) complexes, respectively.

Figure 1. The molecular structure of $\mathrm{Me}_{2} \mathrm{Sn}\left(\mathrm{Quin}-\mathrm{NO}_{2}\right)_{2}$ (1). Thermal ellipsoids at $50 \%$ probability and hydrogen atoms omitted for clarity. Selected bond lengths $(\AA)$ and angles $\left({ }^{\circ}\right)$ : Sn1-N1 2.337, Sn1-O1 2.118; N1-Sn1-N1' 78.3, O1Sn1-O1i 150.5

The reduction of the nitro precursors, $\mathbf{1}$ and $\mathbf{2}$, to the aminefunctionalized complexes was achieved by catalytic hydrogenation with $\mathrm{Pd} / \mathrm{C}$ under an atmosphere of hydrogen. Characterization of the complexes indicated the ${ }^{119} \mathrm{Sn} \mathrm{NMR}$ signals to have shifted upfield to -234 and $-390 \mathrm{ppm}$ for the dimethyl and diphenyl complexes, respectively. The formation of the amine was corroborated in the ${ }^{1} \mathrm{H}$ NMR spectra by the appearance of a broad singlet between 4 and $5 \mathrm{ppm}$ and the appearance of $\mathrm{N}-\mathrm{H}$ stretching frequencies between 3000 and $3500 \mathrm{~cm}^{-1}$ for both complexes. The solid-state structure of $\mathbf{4}$ was also obtained upon recrystallization (Figure 2).

The C-Sn-C angle of 4 was found to be $103.8(3)^{\circ} / 104.3(3)^{\circ}$ (cf. $106.5(2)^{\circ} / 113.3(2)^{\circ}$ for 2 ; two crystallographically distinguishable molecules were present in the asymmetric unit cell of 2 and 4 ), which again resulted in a heavily distorted octahedral structure. The acute angle between the planes of the quinoline substituents was also retained with values of $83.3^{\circ}$ and $83.5^{\circ}$ for the two crystallographically independent molecules. No crystallographically distinguishable change was observed in the length of the six bonds around the tin center to reflect the electronic change of going from the nitro (2) to the amine (4) functionalized complex.

The successful synthesis of the diamine complexes presented the first opportunity to investigate self-assembly reactions. The tin complexes 3 and 4 ( 3 equiv.) were reacted with 2-formylpyridine ( 6 equiv.) in the presence of a series of transition metals ( 2 equiv.), including salts of $\mathrm{Fe}^{\mathrm{II}}, \mathrm{Co}^{\prime \prime}, \mathrm{Mn}^{\mathrm{N}}$ and $\mathrm{Zn} \mathrm{n}^{\mathrm{II}}$. The stoichiometric ratio for an $\mathrm{M}_{2} \mathrm{~L}_{3}$ metallohelicate was chosen to minimize potential

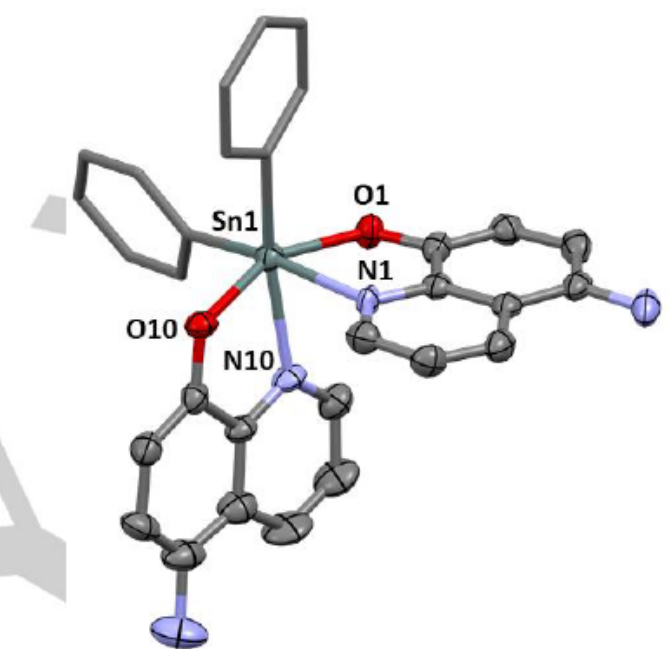

kinetic products, and the reactions stirred for 3 days to allow ample time for the prospective assemblies to equilibrate to the thermodynamic product. Unfortunately, the dark red diamine proligands dominated the color of each assembly and obscured any observation of potentially characteristic color changes arising due to chelation of the metal ions

Figure 2. The molecular structure of $\mathrm{Ph}_{2} \mathrm{Sn}\left(\mathrm{Quin}-\mathrm{NH}_{2}\right)_{2}$ (4). Thermal ellipsoids at $50 \%$ probability and hydrogen atoms omitted for clarity. Selected bond lengths $(\AA)$ and angles $\left({ }^{\circ}\right)$ : Sn1-N1 2.328(5), Sn1-N10 2.293(6), Sn1-O1 2.093(5), Sn1-O10 2.086(5); N1-Sn1-N10 77.0(2), N1-Sn1-O1 75.2(2), N1-Sn1 O10 83.6(2), N10-Sn1-O1 84.2(2), N10-Sn1-O10 75.7(2), O1-Sn1-O10 $153.5(2)$. It should be noted that there were two crystallographically independent molecules of $\mathbf{4}$ present in he asymmetric unit cell, however, the bonds lengths and angles of the two molecules were crystallographically indistinguishable, therefore only one of them is reported herein.

Subsequent crystallization attempts of the self-assemblies yielded no crystals of suitable quality for $\mathrm{X}$-ray diffraction, and NMR and MS data were convoluted and inconclusive. Further diffusion NMR analysis was similarly unable to identify any large aggregates. Due to the increased likelihood of kinetic products at higher concentrations these reactions were performed at concentrations too dilute and on too small scale $(\sim 20 \mu \mathrm{mol})$ to be observed by ${ }^{119} \mathrm{Sn}$ NMR spectroscopy, even with prolonged acquisition times. A ${ }^{1} \mathrm{H}$ NMR titration experiment conducted by adding sequential portions of 0.5 molar equivalents of 2-formylpyridine to a mixture of the 4 ( 3 equiv.) and diamagnetic $\mathrm{Zn}^{\text {"I }}$ (2 equiv.) showed no consumption of the amine or aldehyde 
signals. Heating the mixture to $50^{\circ} \mathrm{C}$ for $12 \mathrm{~h}$ to potentially overcome any kinetic barrier returned no change in the chemical shifts or integrations either. It was therefore concluded that the self-assembly of these potential pro-ligands was inhibited. Understanding the reasons for a lack of supramolecular aggregation could benefit future studies, with the most likely culprits being electronic or steric factors. In particular, while there is literature precedent for the imine condensation of 8-hydroxy-5aminoquinoline, ${ }^{[21]}$ in general, highly aromatic amines are less active towards imine condensation due to the delocalization of the amine lone pair into the aromatic ח-system. In addition to this already inherent deactivation, the quinoline is coordinated to a highly oxidized $\mathrm{Sn}^{\mathrm{IV}}$ center. Therefore, it is reasonable to suggest the amine may be sufficiently deactivated to inhibit the Schiff base formation. Likewise, the bulky octahedral tin pro-ligands may create substantial steric interference, increasing the energy of the fully coordinated assembly to the point that it is energetically unfavorable, and thereby, unable to form altogether.

To investigate the nucleophilic efficacy of the less sterically bulky amine-functionalized tin complex $\mathbf{3}$, attempts were made to isolate the Schiff base ligand outside of self-assembly. Experiments involved modifying the aldehyde in an attempt to induce dative or hydrogen bonding to stabilize, and thereby favor, the imine. However, the reactions of $\mathbf{3}$ with salicylaldehyde and 2formylphenylboronic acid were inconclusive with no shift of the NMR signals being observed. Nevertheless, heating 3 to reflux with 2-formylpyridine and a catalytic amount of acetic acid returned a downfield shift in the ${ }^{119} \mathrm{Sn}$ NMR spectrum to $-228 \mathrm{ppm}$ (cf. $-234 \mathrm{ppm}$ for 3 ). The same change was also observed when trying to trap the imine by chelation with $\mathrm{BaCl}_{2}$. In both cases, the ${ }^{1} \mathrm{H}$ NMR spectra were found to be complex, however, by diffusion NMR spectroscopy a slow diffusing species was able to be identified at $11.4 \times 10-10 \mathrm{~m}^{2} \mathrm{~s}^{-1}$, markedly slower than the parent complex $3\left(14.5 \times 10-10 \mathrm{~m}^{2} \mathrm{~s}^{-1}\right)$. Extraction of the corresponding spectrum using $\operatorname{SCORE}^{[22]}$ (Figure 3 ) matched closely with that expected for the Schiff base, in particular, the strong singlet at 8.8 $\mathrm{ppm}$ in the ${ }^{1} \mathrm{H}$ NMR spectrum is highly characteristic of the resonance expected for an imine.

The results from trapping the assembled tin ligand suggest that the diamine complex is sufficiently nucleophilic to undergo the imine condensation required for self-assembly, which indicated that steric hindrance was the primary factor inhibiting potential supramolecular aggregation. It was therefore decided to probe the steric properties directly by pre-constructing the complete
Schiff base functionalised $\mathrm{Sn}$ complex, $\mathrm{Me}_{2} \mathrm{Sn}$ (Quin-py) ${ }_{2}$ (6; Quin-py = 5-((pyridin-2-ylmethylene)amino)quinolin-8-olate). The complete Schiff base functionalized complex could then be reacted under the same conditions as previously used for the subcomponent self-assembly, thereby isolating the influence of the steric properties.

The synthesis of the assembled ligand (Scheme 2) began with the reduction of $\mathrm{HQuin}-\mathrm{NO}_{2}$ to the corresponding known amine HQuin- $\mathrm{NH}_{2}$ by catalytic hydrogenation. Thereafter, condensation with 2-formylpyridine formed the quinoline-pyridyl Schiff base HQuin-py (5). Finally, reaction of 5 (2 equiv.) with $\mathrm{Me}_{2} \mathrm{SnCl}_{2}$ and a stoichiometric amount of $\mathrm{NEt}_{3}$ (2 equiv.) afforded 6 in a respectable yield of $49 \%$ after purification, with the remaining yield being comprised of unreacted starting materials. Potential sideproducts arising due to chelation of the tin center by the imine/pyridyl were notably not observed, which was attributed to the harder oxygen donor being more favorable over the comparatively softer dative nitrogen bonds of the imine/pyridyl groups.

Scheme 2. The alternative strategy followed to synthesize the complete preconstructed complex $\mathrm{Me}_{2} \mathrm{Sn}$ (Quin-py)2 (6) via the Schiff base (5).

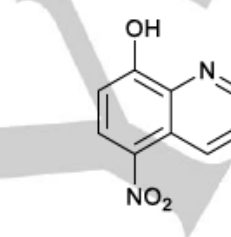<smiles>CO[C@H](O)c1ccc(N)c2cccnc12</smiles><smiles>O=Cc1ccccn1</smiles><smiles>Oc1ccc(/N=C/c2ccccn2)c2cccnc12</smiles>

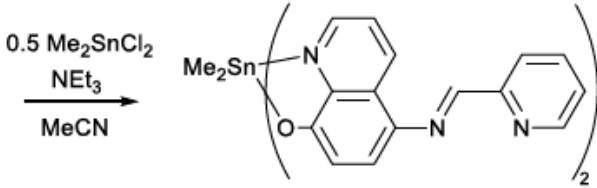

5

Characterization of 6 identified the ${ }^{119} \mathrm{Sn}$ NMR resonance at -228 $\mathrm{ppm}$, correlating well with that found previously by trapping the Schiff base (vide supra). Analysis of the solid-state structure (Figure 4) shows a remarkably acute angle between the quinoline substituents of $72.1^{\circ}$ (cf. $79.5^{\circ}$ for 1 ), which might suggest that

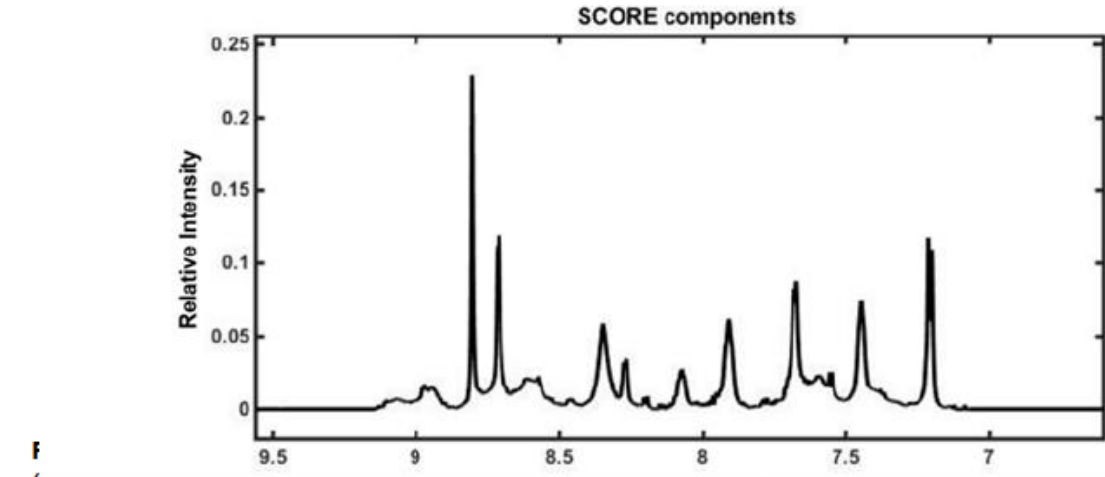

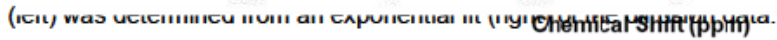

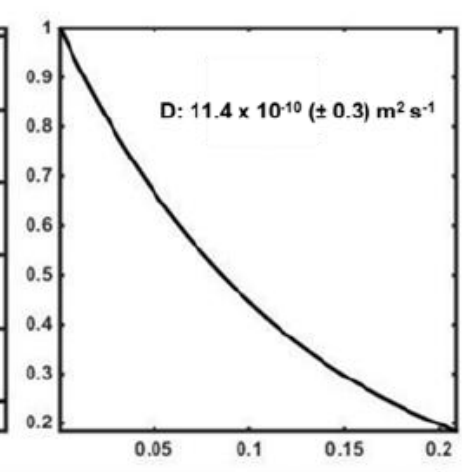

Gradient Amplitude Squared ( $\mathrm{T} \mathrm{m}^{-1}$ ) 
expanding the angle to accommodate the formation of a supramolecular structure would incur an associated energetic penalty that would hinder, if not entirely inhibit, assembly. No crystallographically distinguishable change was observed in the length of the six bonds around the tin center to reflect the electronic change of going from the nitro (1) to the Schiff base (6) functionalized complex, and warrants no further comment. Similar to $\mathbf{5}$, the pyridyl substituents in the solid-state structure of $\mathbf{6}$ adopt an anti conformation with the imine to minimize electronic repulsion between the two nitrogen lone pairs.

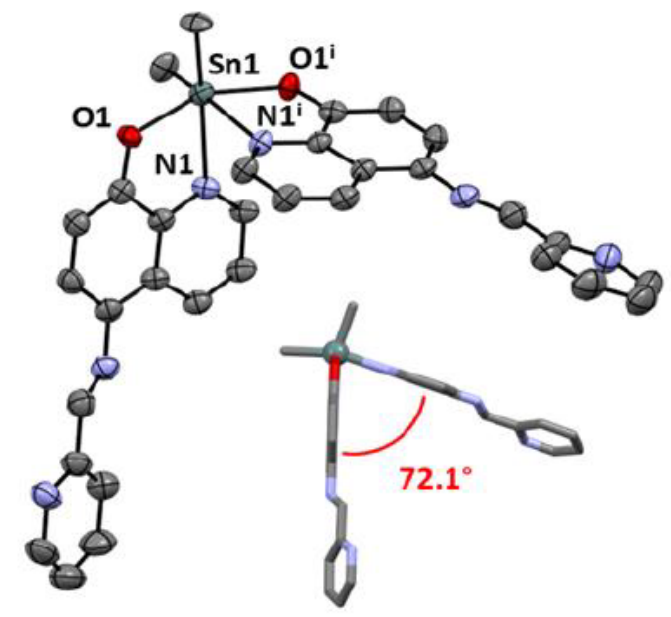

Figure 4. The molecular structure of $\mathrm{Me}_{2} \mathrm{Sn}(\text { Quin-py) })_{2}$ (6). Thermal ellipsoids at $50 \%$ probability and hydrogen atoms omitted for clarity. Inset bottom right: the acute angle $\left(72.1^{\circ}\right)$ between the planes of the two Quin-py substituents of 6 . Selected bond lengths $(\AA)$ and angles $\left({ }^{\circ}\right)$ : Sn1-N1 2.343, Sn1-O1 2.104; N1Sn1-N1 13.8 , O1-Sn1-O1' 154.0 .

Following the successful synthesis of the pre-constructed complex, it was then combined in acetonitrile with $\mathrm{Fe}\left[\mathrm{BF}_{4}\right]_{2}$ in a stoichiometric ratio of 3:2 (complex 6:metal) and stirred for 3 days. Analysis of the resulting dark red mixture by 1D NMR, diffusion NMR, and mass spectrometry returned convoluted spectra, however, ultimately no evidence was able to be found for the formation of the metallohelicate or any other large supramolecular aggregate.

In response to this, 4-coordinate tin complexes were envisioned to trim down the steric shrubbery around the tin center. Therefore, an analogous route to that described for the six-coordinate complexes was envisaged to access the less sterically congested 4-coordinate tin complexes. The reaction of $\mathrm{SnCl}_{2}$ with two equivalents of HQuin- $\mathrm{NO}_{2}$ and $\mathrm{NEt}_{3}$ rapidly turned dark red. However, subsequent analysis indicated that the chlorides had not been displaced as intended, and instead the addition of the

‡ ${ }^{1} \mathrm{H}$ NMR $\left(400 \mathrm{MHz}, \mathrm{CD}_{3} \mathrm{CN}\right) \delta 9.80(\mathrm{~d}, J=8.9 \mathrm{~Hz}, 1 \mathrm{H}), 8.93(\mathrm{~d}, J=$ $4.7 \mathrm{~Hz}, 1 \mathrm{H}), 8.79(\mathrm{~d}, J=8.9 \mathrm{~Hz}, 1 \mathrm{H}), 8.16(\mathrm{dd}, J=8.8,5.1 \mathrm{~Hz}, 1 \mathrm{H})$ $7.46(\mathrm{~d}, J=8.9 \mathrm{~Hz}, 1 \mathrm{H})$. quinoline ligands had formed an octahedral complex, oxidizing the tin center from +2 to +4 in the process.

The formation of $\mathrm{Cl}_{2} \mathrm{Sn}$ (Quin- $\left.\mathrm{NO}_{2}\right)_{2}$ (previously prepared to explore its fluorescent properties), ${ }^{[23]}$ while unintended, did still provide a potential pathway to the target 4-coordinate complex. A silver-anion exchange was attempted to collapse the octahedral complex back to the desired 4-coordinate structure and initial results of the reaction with $\mathrm{Ag}\left[\mathrm{SbF}_{6}\right]$ were promising. The NMR analysis of the product ${ }^{\ddagger}$ showed a single set of quinoline peaks, shifted significantly from the free ligand ${ }^{\S}$. Additionally, HR-MS identified the protonated parent ion of the neutral 4-coordinate species with isotope matching showing good agreement. However, an inability to confidently characterize this complex has hindered further studies, with research ongoing. The results illustrate the challenge of stabilizing the lower 4-coordinate $\mathrm{Sn}^{\mathrm{IV}}$ center sufficiently to be amenable to sub-component selfassembly.

\section{Conclusions}

The precursor tin complexes $\mathrm{Me}_{2} \mathrm{Sn}\left(\text { Quin- }-\mathrm{NO}_{2}\right)_{2}$ (1) and $\mathrm{Ph}_{2} \mathrm{Sn}$ (Quin- $\left.\mathrm{NO}_{2}\right)_{2}$ (2) were synthesized in good yields, then straightforwardly reduced into their more synthetically versatile amine-functionalized analogues $\mathrm{Me}_{2} \mathrm{Sn}\left(\text { Quin- } \mathrm{NH}_{2}\right)_{2}$ (3) and $\mathrm{Ph}_{2} \mathrm{Sn}$ (Quin- $\left.\mathrm{NH}_{2}\right)_{2}$ (4) using $\mathrm{Pd} / \mathrm{C}$ and hydrogen gas. Subsequent analysis of $\mathbf{3}$ and $\mathbf{4}$ revealed that the amino groups were largely insensitive toward the formation of Schiff bases, even 'trapped' Schiff bases stabilized by coordination to a metal center. Synthesis of the pre-constructed complex $\mathrm{Me}_{2} \mathrm{Sn}$ (Quin-py) ${ }_{2}$ (6) via a revised methodology demonstrated that the Schiff bases could be installed and tolerated by the tin center without issue. However, the increased acute angle found between the quinoline substituents (confirmed as a favorable arrangement in the solidstate studies) compellingly indicated a steric impediment for supramolecular aggregation. Substituents that would enforce a wider angle than the quinoline reported here, as well as less coordinately saturated tin complexes $(<6)$, are currently being pursued to continue probing the potential of Schiff base functionalized tin complexes.

\section{Experimental Section}

\section{General Methods}

All reactions were performed under dry nitrogen using standard Schlenk techniques with anhydrous, degassed solvents unless otherwise noted. Acetonitrile was dried over $\mathrm{CaH}_{2}$, methanol was dried over $\mathrm{Mg}$ filings followed by vacuum distillation, and triethylamine was dried over $4 \AA$ molecular sieves prior to use. All uncharacterised chemicals were obtained from commercial suppliers and used as received.

§ 1 $\mathrm{H}$ NMR $\left(400 \mathrm{MHz}, \mathrm{CD}_{3} \mathrm{CN}\right) \delta 9.23(\mathrm{~d}, \mathrm{~J}=8.9 \mathrm{~Hz}, 1 \mathrm{H}), 8.94$ (d, J $=4.2 \mathrm{~Hz}, 1 \mathrm{H}), 8.56(\mathrm{~d}, \mathrm{~J}=8.8 \mathrm{~Hz}, 2 \mathrm{H}), 7.82(\mathrm{dd}, \mathrm{J}=8.9,4.2 \mathrm{~Hz}$, $2 \mathrm{H}), 7.22(\mathrm{~d}, \mathrm{~J}=8.7 \mathrm{~Hz}, 1 \mathrm{H})$. 
NMR spectra were collected at $298 \mathrm{~K}$ on a Bruker Avance III $400(400 \mathrm{MHz}$ for ${ }^{1} \mathrm{H}, 101 \mathrm{MHz}$ for ${ }^{13} \mathrm{C}$, and $149 \mathrm{MHz}$ for $\left.{ }^{119} \mathrm{Sn}\right)$, Bruker Avance $600(600$ $\mathrm{MHz}$ for ${ }^{1} \mathrm{H}, 151 \mathrm{MHz}$ for $\left.{ }^{13} \mathrm{C}\right)$, and Bruker Ascend $700\left(700 \mathrm{MHz}\right.$ for ${ }^{1} \mathrm{H}$, $176 \mathrm{MHz}$ for ${ }^{13} \mathrm{C}$ ) spectrometers. Chemical shifts ( $\delta$ ) are reported in ppm and coupling constants $(J)$ are measured in $\mathrm{Hz} .{ }^{1} \mathrm{H}$ and ${ }^{13} \mathrm{C}\left\{{ }^{1} \mathrm{H}\right\}$ chemical shifts are reported relative to the relevant residual solvent, whereas an external reference $(\delta=0.00 \mathrm{ppm})$ was used for ${ }^{119} \mathrm{Sn}\left(\mathrm{Me}_{4} \mathrm{Sn}\right)$. Assignments are supported by 2D NMR analysis.

Diffusion NMR data was collected on a Bruker Avance 600 at $298 \mathrm{~K}$ fitted with a $5 \mathrm{~mm} \mathrm{CP} \mathrm{TCl}$ probe and z-gradient coil of $5.35 \times 10^{-4} \mathrm{~T} \mathrm{~cm}^{-1}$ maximum field strength. The convection compensated pulse program, dstebpgp3s, was used to mitigate the low viscosity of $d_{3}$-acetonitrile. The gradient pulse length and diffusion time were determined individually for each sample by cal brating the parameters required for $95 \%$ signal attenuation at $95 \%$ gradient strength. All experiments were conducted by increasing the gradient strength from $2-90 \%$ in 16 equal steps. Diffusion data was processed by Dynamics Centre. Errors were estimated from the standard error of the regression model and compared with the diffusion coefficient range as indicated by the HR-DOSY plot.

Small molecule HR-ESI MS was performed on a Waters LCT Premier OATOF mass spectrometer operated by the RSC Joint Mass Spec Facility. Analyses including isotope matching and error estimation were determined using Thermo Xcalibur.

Small molecule single-crystal X-ray diffraction data was obtained with an Oxford Diffraction SuperNova diffractometer at $150 \mathrm{~K}$. The data was collected and reduced using CrysAlisPro. All structures were solved within Olex $2^{[24]}$ by SheIXT ${ }^{[25]}$ with refinement by SheIXL. ${ }^{[26]}$

\section{Experimental}

General procedure for the synthesis of nitro-functionalised 6coordinate tin complexes [1 and 2]: To an acetonitrile (18 mL) solution of 8-hydroxy-5-nitroquinoline (173 mg, $0.91 \mathrm{mmol})$ was added triethylamine $(0.137 \mathrm{~mL}, 0.91 \mathrm{mmol})$. The resulting orange solution was frozen with liquid nitrogen and the organotin reagent $(0.46 \mathrm{mmol})$ was added. While still frozen, the reaction flask was evacuated and backfilled with nitrogen (x4) then allowed to warm to ambient temperature before being heated to reflux for $8 \mathrm{~h}$. Thereafter, all volatiles were removed under reduced pressure and the crude product resuspended in methanol $(25 \mathrm{~mL})$ After sonicating for $80 \mathrm{~min}$, the product was isolated by filtration.

Dimethyltin bis(5-nitroquinolin-8-olate) [1]: Obtained as a yellow solid. $\mathrm{X}$-ray diffraction quality crystals were afforded by vapour diffusion of diisopropyl ether into a concentrated DCM solution of 1. Yield 79\% (207 $\mathrm{mg}, 0.36 \mathrm{mmol}$ ). ${ }^{1} \mathrm{H} \mathrm{NMR}\left(700 \mathrm{MHz}, \mathrm{CDCl}_{3}\right): \delta 9.48$ (d, J = $7.0 \mathrm{~Hz}, 2 \mathrm{H}$ ), 8.75 (d, J = $8.8 \mathrm{~Hz}, 2 \mathrm{H}$ ), 8.54 (d, J = 4.9 Hz, 2H), 7.55 (dd, J = 7.0, 4.9, $2 \mathrm{H}), 7.23(\mathrm{~d}, \mathrm{~J}=7.0 \mathrm{~Hz}, 2 \mathrm{H}), 0.54(\mathrm{~s}, 6 \mathrm{H}) .{ }^{13} \mathrm{C}\left\{{ }^{1} \mathrm{H}\right\} \mathrm{NMR}\left(101 \mathrm{MHz}, \mathrm{CDCl}_{3}\right)$ o $164.6(2 \times \mathrm{C}), 143.3(2 \times \mathrm{CH}), 137.2(2 \times \mathrm{CH}), 135.0(2 \times \mathrm{C}), 132.3(2 \times$ $\mathrm{CH}), 131.8(2 \times \mathrm{C}), 125.2(2 \times \mathrm{CH}), 124.8(2 \times \mathrm{C}), 112.6(2 \times \mathrm{CH}), 7.8(2 \times$ $\mathrm{CH}_{3}$ ). ${ }^{119} \mathrm{Sn}$ NMR (149 MHz, $\left.\mathrm{CDCl}_{3}\right): \delta-214.6$ (s). IR: 3064, 3007, 1604, $1500,1460,1386,1286,1097,741,447 \mathrm{~cm}^{-1}$. HR-ESI(+ve ion): Found: $\mathrm{m} / \mathrm{z}=550.9995$. Calc'd for $\left[\mathrm{C}_{20} \mathrm{H}_{16} \mathrm{~N}_{4} \mathrm{O}_{6} \mathrm{Sn}+\mathrm{Na}^{+} 550.9990[\mathrm{M}+\mathrm{Na}]^{+}\right.$. Anal.
Found: C 45.57, $\mathrm{H}, 2.91 ; \mathrm{N}, 10.62 \%$. Calcd for $\mathrm{C}_{20} \mathrm{H}_{10} \mathrm{~N}_{4} \mathrm{O}_{8} \mathrm{Sn}: \mathrm{C}, 45.58 ; \mathrm{H}$, $3.06 ; \mathrm{N}, 10.63 \%$.

Diphenyltin bis(5-nitroquinolin-8-olate) [2]: Obtained as a yellow solid $\mathrm{X}$-ray diffraction quality crystals were afforded by vapour diffusion of pet. spirits into a concentrated DCM solution of 2. Yield $73 \%(221 \mathrm{mg}, 0.34$ mmol). ${ }^{1} \mathrm{H}$ NMR (400 MHz, $\left.\mathrm{CDCl}_{3}\right)$ : $\delta 9.47(\mathrm{~s}, 2 \mathrm{H}), 8.78$ (dd, J = Hz, 2H), $8.61(\mathrm{~s}, 2 \mathrm{H}), 7.62-7.44(\mathrm{~m}, \mathrm{H}), 7.38(\mathrm{~d}, \mathrm{~J}=\mathrm{Hz}, 2 \mathrm{H}), 7.27(\mathrm{~m}, 2 \mathrm{H}) .{ }^{13} \mathrm{C}\left\{{ }^{1} \mathrm{H}\right\}$ NMR (101 MHz, CDCl $)_{3} \delta 164.4(2 \times \mathrm{C}), 147.2(2 \times \mathrm{C}), 143.8(2 \times \mathrm{CH})$, $137.7(2 \times \mathrm{CH}), 134.9(2 \times \mathrm{C}), 134.7(4 \times \mathrm{CH}), 132.3(2 \times \mathrm{CH}), 129.3(2 \times$ $\mathrm{CH}), 128.7(4 \times \mathrm{CH}), 128.3(2 \times \mathrm{C}), 125.3(2 \times \mathrm{CH}), 124.6(2 \times \mathrm{C}), 113.0(2$ x CH). ${ }^{119} \mathrm{Sn}$ NMR (149 MHz, $\left.\mathrm{CDCl}_{3}\right) \delta-381.6$ (s). IR: 3064, 2978, 1603 $1566,1501,1490,1460,1285,1095,740 \mathrm{~cm}^{-1}$. HR-ESI(+ve ion): Found: $\mathrm{m} / \mathrm{z}=675.0302$. Calc'd for $\left[\mathrm{C}_{30} \mathrm{H}_{20} \mathrm{~N}_{4} \mathrm{O}_{6} \mathrm{Sn}+\mathrm{Na}\right]^{+} 675.0303[\mathrm{M}+\mathrm{Na}]^{+}$. Anal Found: $\mathrm{C} 55.30, \mathrm{H}, 3.03 ; \mathrm{N}, 8.56 \%$. Calcd for $\mathrm{C}_{30} \mathrm{H}_{20} \mathrm{~N}_{4} \mathrm{O}_{6} \mathrm{Sn}$ : C, 55.33; $\mathrm{H}$, $3.10 ; \mathrm{N}, 8.60 \%$

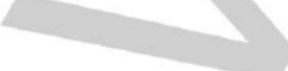

General procedure for the synthesis of diamine 6-coordinate tin complexes [ 3 and 4]: The nitro-precursor complex and $\mathrm{Pd} / \mathrm{C}$ (5\% w/w) were combined in methanol $(14 \mathrm{~mL})$. The mixture was evacuated and sealed under an atmosphere of $\mathrm{H}_{2}$ before stirring for 8 hours. The resulting dark mixture was then filtered through a pad of Celite and washed with excess methanol ( $100 \mathrm{~mL})$. Thereafter the solvent was removed under reduced pressure to yield the free-base product.

Dimethyltin bis(5-aminoquinolin-8-olate) [3]: Obtained as a red solid Yield 51\% (111 mg, $0.24 \mathrm{mmol}$ ). ${ }^{1} \mathrm{H}$ NMR (700 MHz, $\mathrm{CD}_{3} \mathrm{CN}$ ) $\delta 8.42$ (d, J $=4.5 \mathrm{~Hz}, 2 \mathrm{H}), 8.25$ (d, J = 8.4 Hz, 2H), 7.17 (dd, J = 8.3, $4.6 \mathrm{~Hz}, 2 \mathrm{H}), 6.95$ (d, J = 8.2 Hz, 2H), 6.84 (d, J = 8.2 Hz, 2H), 4.06 (br s, 4H), 0.22 (s, 6H). ${ }^{13} \mathrm{C}\left\{{ }^{1} \mathrm{H}\right\}$ NMR $\left(176 \mathrm{MHz}, \mathrm{CD}_{3} \mathrm{CN}\right) \delta 150.9(2 \times \mathrm{C}), 143.4(2 \times \mathrm{CH}), 136.8(2$ $x$ C), $134.9(2 \times \mathrm{C}), 132.4(2 \times \mathrm{C}), 121.4(2 \times \mathrm{CH}), 120.5(2 \times \mathrm{CH}), 114.4(2$ $x \mathrm{CH}), 114.0(2 \times \mathrm{CH}), 6.2\left(2 \times \mathrm{CH}_{3}\right) .{ }^{119} \mathrm{Sn}\left(149 \mathrm{MHz}, \mathrm{CD}_{3} \mathrm{CN}\right) \delta-234$ (s) IR: $3326,3213,1597,1573,1459,1419,1385,1367,1282,1092,779$, $720 \mathrm{~cm}^{-1}$. HR-ESI(+ve ion): Found: $\mathrm{m} / \mathrm{z}=$ 491.0513. Calc'd for $\left[\mathrm{C}_{20} \mathrm{H}_{20} \mathrm{~N}_{4} \mathrm{O}_{2} \mathrm{Sn}+\mathrm{Na}\right]^{+} 491.0506[\mathrm{M}+\mathrm{Na}]^{+}$.

Diphenyltin bis(5-aminoquinolin-8-olate) [4]: Obtained as a red solid. Xray diffraction quality crystals were afforded by vapour diffusion of diisopropyl ether into a concentrated DCM solution of 4 doped with $5 \mu$ of benzene. Yield $74 \%$ (78.5 mg, $0.11 \mathrm{mmol})$. ${ }^{1} \mathrm{H} \mathrm{NMR}\left(600 \mathrm{MHz}, \mathrm{CD}_{3} \mathrm{CN}\right) \delta$ $8.51(\mathrm{~s}, 2 \mathrm{H}), 8.28$ (d, $J=8.2 \mathrm{~Hz}, 2 \mathrm{H}), 7.58-7.44(\mathrm{~m}, 4 \mathrm{H}), 7.25-7.16(\mathrm{~m}$, $8 \mathrm{H}), 7.11$ (d, $J=8.1 \mathrm{~Hz}, 2 \mathrm{H}), 6.89$ (d, $J=10.4 \mathrm{~Hz}, 2 \mathrm{H}), 4.15$ (br s, 4H) ${ }^{13} \mathrm{C}\left\{{ }^{1} \mathrm{H}\right\}$ NMR (151 MHz, CD $\left.{ }_{3} \mathrm{CN}\right)$ : $\delta 151.7(2 \times \mathrm{C}), 150.4(2 \times \mathrm{C}), 146.4(2$ x C), $143.9(2 \times \mathrm{C}), 136.7(2 \times \mathrm{C}), 135.7(2 \times \mathrm{CH}), 133.1(2 \times \mathrm{CH}), 129.0(2$ $x \mathrm{CH}) 128.8(2 \times \mathrm{CH}), 121.3(2 \times \mathrm{CH}), 120.6(2 \times \mathrm{CH}), 114.7(2 \times \mathrm{CH})$, 114.4 ( 2 x CH). ${ }^{119} \mathrm{Sn} \mathrm{NMR}\left(149 \mathrm{MHz}, \mathrm{CD}_{3} \mathrm{CN}\right) \bar{\delta}-390.7$ (s). IR: 3334,3225 , $3060,1597,1573,1458,1419,1384,1367,1282,1092,728,698 \mathrm{~cm}^{-1}$. HR-ESI(+ve ion): Found: $\mathrm{m} / \mathrm{z}=593.1007$. Calc'd for $\left[\mathrm{C}_{30} \mathrm{H}_{24} \mathrm{~N}_{4} \mathrm{O}_{2} \mathrm{Sn}+\mathrm{H}\right]^{+}$ $593.1000\left[\mathrm{M}+\mathrm{H}^{+}\right.$. Anal. Found: C 55.18, H, 3.67; N, 8.59\%. Calcd for $\mathrm{C}_{30} \mathrm{H}_{20} \mathrm{~N}_{4} \mathrm{O}_{6} \mathrm{Sn} \cdot \mathrm{CHCl}_{2}: \mathrm{C}, 55.07 ; \mathrm{H}, 3.88 ; \mathrm{N}, 8.29 \%$ 
8-hydroxy-5-aminoquinoline: Adapted from Sleath ${ }^{[2]}$ To methanol (14 $\mathrm{mL}$ ) was added 8-hydroxy-5-nitroquinoline $(400 \mathrm{mg}, 2.1 \mathrm{mmol})$ and $\mathrm{Pd} / \mathrm{C}$ $(40 \mathrm{mg}, 10 \% \mathrm{w} / \mathrm{w})$. The flask was evacuated and backfilled with hydrogen (x3) before stirring under an atmosphere of $\mathrm{H}_{2}$ gas for $3.5 \mathrm{~h}$. The resulting dark green reaction mixture was filtered through celite and washed with excess methanol $(\sim 100 \mathrm{~mL})$ until the filtrate ran clear. The solvent was then removed under reduced pressure to give a dark red solid. Yield $98 \%$ (337 mg, $2.1 \mathrm{mmol}$ ). ${ }^{1} \mathrm{H}$ NMR (400 MHz, d $d_{8}$-acetone) $\delta 8.77$ (s, 1H), 8.49 (d, J = 8.5 Hz, 1H), $7.47(\mathrm{~s}, 1 \mathrm{H}), 6.92(\mathrm{~d}, \mathrm{~J}=8.0 \mathrm{~Hz}, 1 \mathrm{H}), 6.78(\mathrm{~d}, \mathrm{~J}=8.0$ $\mathrm{Hz}, 1 \mathrm{H}), 4.84$ (br s, 2H). ${ }^{13} \mathrm{C}$ NMR (101 MHz, de-acetone) $\delta 148.6(\mathrm{CH})$, 145.4 (C), 139.4 (C), 137.0 (C), $132.1(\mathrm{CH}), 120.7$ (C), $120.1(\mathrm{CH}), 111.2$ $(\mathrm{CH}), 110.5(\mathrm{CH})$. ESI-MS(+ve ion): Found: $\mathrm{m} / \mathrm{z}=161.2$ Calcd for $\left[\mathrm{C}_{8} \mathrm{H}_{8} \mathrm{~N}_{2} \mathrm{O}+\mathrm{H}\right]^{+} 161.2\left[\mathrm{M}+\mathrm{H}^{+}\right.$.

5-((Pyridin-2-ylmethylene)amino)quinolin-8-ol [5]: To an open flask was added 8-hydroxy-5-aminoquinoline (337 mg, $2.1 \mathrm{mmol}$ ), 2formylpyridine $(0.20 \mathrm{ml}, 2.1 \mathrm{mmol})$ and ethanol $(25 \mathrm{~mL})$. Acetic acid $(2$ drops) was added and the dark red mixture heated to reflux for 3 hours, following which the solvent was removed. The crude product was then purified by recrystallisation from ethanol:acetone $(3: 1$, v:v) to obtain the product as a brown powder. X-ray diffraction quality crystals were afforded by vapour diffusion of diisopropyl ether into a concentrated DCM solution of 5. Yield $7 \%$ ( $39.4 \mathrm{mg}, 0.15 \mathrm{mmol}$ ). ${ }^{1} \mathrm{H}$ NMR $\left(400 \mathrm{MHz}, \mathrm{CDCl}_{3}\right) \delta 8.85$ (d, $\mathrm{J}=4.2 \mathrm{~Hz}, 1 \mathrm{H}), 8.84(\mathrm{~s}, 1 \mathrm{H}), 8.77(\mathrm{~s}, 1 \mathrm{H}), 8.74(\mathrm{~d}, \mathrm{~J}=4.5 \mathrm{~Hz}, 1 \mathrm{H}), 8.36$ (d, J = 7.9 Hz, 1H), $7.86(\mathrm{t}, \mathrm{J}=8.4 \mathrm{~Hz}, 1 \mathrm{H}), 7.52(\mathrm{~d}, \mathrm{~J}=4.9 \mathrm{~Hz}, 1 \mathrm{H}), 7.39$ (dd, J = 7.4, $4.9 \mathrm{~Hz}, 1 \mathrm{H}), 7.34(\mathrm{~d}, \mathrm{~J}=8.2 \mathrm{~Hz}, 1 \mathrm{H}), 7.20(\mathrm{~d}, \mathrm{~J}=8.2 \mathrm{~Hz}, 1 \mathrm{H})$, $5.30(\mathrm{~s}, 1 \mathrm{H}) .{ }^{13} \mathrm{C}\left\{{ }^{1} \mathrm{H}\right\} \mathrm{NMR}\left(101 \mathrm{MHz}, \mathrm{CDCl}_{3}\right) \delta 159.1(\mathrm{CH}), 155.1(\mathrm{C})$, $151.7(\mathrm{C}), 149.9(\mathrm{CH}), 148.6(\mathrm{CH}), 138.9(\mathrm{C}), 138.3(\mathrm{C}), 136.8(\mathrm{CH}), 133.2$ $(\mathrm{CH}), 125.3(\mathrm{C}), 125.2(\mathrm{CH}), 121.9(\mathrm{CH}), 121.9(\mathrm{CH}), 114.3(\mathrm{CH}), 109.9$ (CH). HR-ESI(+ve ion): Found: $\mathrm{m} / \mathrm{z}=250.0983$. Calc'd for $\left[\mathrm{C}_{15} \mathrm{H}_{11} \mathrm{~N}_{3} \mathrm{O}+\right.$ $\mathrm{H}]^{+} 250.0980[\mathrm{M}+\mathrm{H}]^{+}$

\section{Dimethyltin bis(5-((pyridin-2-ylmethylene)amino)quinolin-8-olate) [6]} The Schiff base 5 ( $30.9 \mathrm{mg}, 0.12 \mathrm{mmol})$, was dissolved in acetonitrile ( 20 $\mathrm{mL})$ and triethylamine $(0.02 \mathrm{~mL}, 0.12 \mathrm{mmol})$ was added. The reaction was stirred 10 min before freezing with liquid nitrogen and adding $\mathrm{Me}_{2} \mathrm{SnCl}_{2}$ (13.6 $\mathrm{mg}, 0.06 \mathrm{mmol}$ ). While still frozen, the reaction flask was evacuated and backfilled with nitrogen $(x 4)$ then allowed to warm to ambient temperature before being heated to reflux for $8 \mathrm{~h}$. Thereafter the solvent was removed under reduced pressure and the resulting brown solid was then extracted into dichloromethane $(20 \mathrm{~mL})$ and washed with water $(5 \mathrm{x}$ $20 \mathrm{~mL})$ and brine $(2 \times 20 \mathrm{~mL})$, dried over sodium sulfate, and evaporated to give a dark red solid. $\mathrm{X}$-ray diffraction quality crystals were afforded by vapour diffusion of diisopropyl ether into a concentrated DCM solution of 6. Yield $49 \%$ (19.5 mg, $0.03 \mathrm{mmol}$ ). ${ }^{1} \mathrm{H}$ NMR $\left(400 \mathrm{MHz}, \mathrm{CDCl}_{3}\right) \delta 8.87$ (d, $J=8.4 \mathrm{~Hz}, 2 \mathrm{H}), 8.78(\mathrm{~s}, 2 \mathrm{H}), 8.72-8.68(\mathrm{~m}, 2 \mathrm{H}), 8.58-8.54(\mathrm{~m}, 2 \mathrm{H})$, $8.37-8.22(\mathrm{~m}, 4 \mathrm{H}), 7.80(\mathrm{t}, J=7.7 \mathrm{~Hz}, 2 \mathrm{H}), 7.57$ (d, $J=8.5 \mathrm{~Hz}, 2 \mathrm{H}), 7.37$ - $7.32(\mathrm{~m}, 2 \mathrm{H}), 7.29(\mathrm{~s}, 2 \mathrm{H}), 0.49(\mathrm{~s}, 6 \mathrm{H}) .{ }^{13} \mathrm{C}\left\{{ }^{1} \mathrm{H}\right\} \mathrm{NMR}\left(176 \mathrm{MHz}, \mathrm{CDCl}_{3}\right)$ б $157.6(2 \times \mathrm{C}), 156.8(2 \times \mathrm{CH}), 155.4(2 \times \mathrm{C}), 149.8(2 \times \mathrm{CH}), 143.1(2 \times$ $\mathrm{CH}), 136.8(2 \times \mathrm{C}), 136.7(2 \times \mathrm{CH}), 136.0(2 \times \mathrm{CH}), 135.9(2 \times \mathrm{CH}), 133.8$ $(2 \times \mathrm{C}), 127.1(2 \times \mathrm{C}), 124.8(2 \times \mathrm{CH}), 121.5(2 \times \mathrm{CH}), 117.1(2 \times \mathrm{CH})$, $113.6(2 \times \mathrm{CH}), 7.3\left(2 \times \mathrm{CH}_{3}\right) .{ }^{119} \mathrm{Sn} \mathrm{NMR}\left(149 \mathrm{MHz}, \mathrm{CDCl}_{3}\right) \delta-228.9$ (s). IR: $3052,2963,1615,1566,1462,1316,1258,1096,1015,779,729,518$ $\mathrm{cm}^{-1}$. HR-ESI(+ve ion): Found: $\mathrm{m} / \mathrm{z}=647.1220$. Calc'd for $\left[\mathrm{C}_{32} \mathrm{H}_{26} \mathrm{~N}_{8} \mathrm{O}_{2} \mathrm{Sn}\right.$ $+\mathrm{H}^{+} 647.1217\left[\mathrm{M}+\mathrm{H}^{+}\right.$.

\section{Acknowledgments}

The authors would like to thank the ANU Research School of Chemistry Analytical Department for all their time and patience throughout this work.

Keywords: Tin $\cdot$ Schiff bases $\cdot$ Coordination Chemistry: Structure $\cdot$ Main group elements

[1] D. A. Evans, D. W. C. MacMillan, K. R. Campos, J. Am. Chem. Soc 1997, 119, 10859-10860

[2] Y. Ding, X. Liu, X. Ma, Y. Liu, M. Zhong, W. Li, Z. Yang, Y. Yang, J. Organomet. Chem. 2018, 868, 55-60.

[3] R. R. Holmes, Acc. Chem. Res. n.d., 190-197

[4] C. E. Carraher, M. R. Roner, J. Organomet. Chem. 2014, 751, 67-82.

[5] V. Chandrasekhar, Coord. Chem. Rev. 2002, 52.

[6] J.-C. Choi, T. Sakakura, T. Sako, J. Am. Chem. Soc. 1999, 121 3793-3794.

[7] F. R. Abreu, M. B. Alves, C. C. S. Macêdo, L. F. Zara, P. A. Z. Suarez, J. Mol. Catal. A: Chem. 2005, 227, 263-267

[8] S. Einloft, T. O. Magalhães, A. Donato, J. Dullius, R. Ligabue, Energ Fuel 2008, 22, 671-674.

[9] R. Shankar, M. Kumar, R. K. Chadha, G. Hundal, Inorganic Chemistry 2003, 42, 8585-8591

[10] M. Vafaee, M. M. Amini, H. R. Khavasi, S. W. Ng, E. R. T. Tiekink, Applied Organometallic Chemistry 2012, 26, 471-477.

[11] M. J. Clarke, F. Zhu, D. R. Frasca, Chemical Reviews 1999, 99, 25112534.

[12] L. Pellerito, Coordination Chemistry Reviews 2002, 224, 111-150

[13] P.-F. Cao, A. Bunha, J. Mangadlao, M. J. Felipe, K. I. Mongcopa, R Advincula, Chem Commun 2012, 48, 12094.

[14] D. Das, S. S. Mohapatra, S. Roy, Chem. Soc. Rev. 2015, 44, 36663690 .

[15] J. Jiao, C. Tan, Z. Li, Y. Liu, X. Han, Y. Cui, Journal of the American Chemical Society 2018, DOI 10.1021/jacs.7b11679.

[16] S. W. S. Choy, M. J. Page, M. Bhadbhade, B. A. Messerle, Organometallics 2013, 32, 4726-4729.

[17] V. C. Gibson, C. Redshaw, G. A. Solan, Chem. Rev. 2007, 107, 17451776.

[18] D. L. Davies, F. Lelj, M. P. Lowe, K. S. Ryder, K. Singh, S. Singh, Dalton Trans. 2014, 43, 4026-4039.

[19] I. A. Riddell, M. M. J. Smulders, J. K. Clegg, J. R. Nitschke, Chem Commun. 2010, 47, 457-459

[20] V. . Kumar Das, Y. Chee-Keong, P. J. Smith, Journal of Organometallic Chemistry 1987, 327, 311-326.

[21] H.-L. Gao, X.-P. Zhou, Y.-X. Bi, H.-Y. Shen, W.-M. Wang, N.-N. Wang Y.-X. Chang, R.-X. Zhang, J.-Z. Cui, Dalton Trans. 2017, 46, 46694677.

[22] M. Nilsson, G. A. Morris, Anal. Chem. 2008, 80, 3777-3782

[23] Y. Fazaeli, M. M. Amini, E. Najafi, E. Mohajerani, M. Janghouri, A. Jalilian, S. W. Ng, J. Fluoresc. 2012, 22, 1263-1270

[24] O. V. Dolomanov, L. J. Bourhis, R. J. Gildea, J. a. K. Howard, H Puschmann, J Appl Cryst 2009, 42, 339-341.

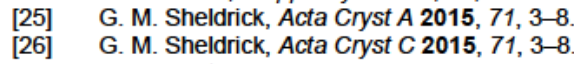

[27] P. R. Sleath, J. B. Noar, G. A. Eberlein, T. C. Bruice, J. Am. Chem. Soc. $1985,107,3328-3338$. 
Entry for the Table of Contents (Please choose one layout)

Layout 1:

\section{FULL PAPER}

A series of $\mathrm{Sn}^{\mathrm{IV}}$ complexes bearing functionalized bidentate quinoline substituents of the form $\mathrm{R}_{2} \mathrm{Sn}$ (Quin) 2 have been synthesized and their synthetic utility explored. Species were fully characterized by a range of techniques including NMR (with ${ }^{119} \mathrm{Sn}$ NMR spectroscopy), HR-ESI MS and single-crystal X-ray diffraction.

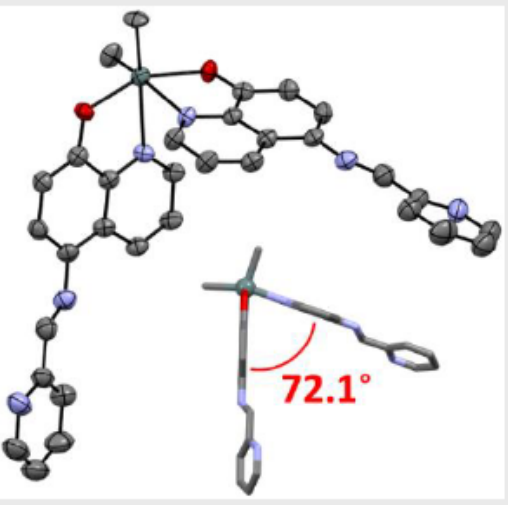

*one or two words that highlight the emphasis of the paper or the field of the study
Tin, Schiff bases, Coordination Chemistry: Structure*

Patrick W. V, Butler and Jas S. Ward

Page No. - Page No.

The Synthesis of Quinoline-based Tin Complexes with Pendant Schiff Bases 